fournal of Medical Genetics (1971). 8, 222.

\title{
Ring 13 Chromosome with Normal Haptoglobin Inheritance*
}

\author{
JOSEPH G. HOLLOWELL, $†$ L. GAYLE LITTLEFIELD, $\ddagger$ AYUT DHARMKRONG-AT, \\ GORDON M. FOLGER, CLARK W. HEATH Jr, and GERALD E. BLOOM**
}

From the Medical College of Georgia, Augusta, Georgia, the National Communicable Disease Center, Atlanta, Georgia, and the Children's Hospital Medical Center, Boston, Massachusetts, USA

The combination of cytogenetic, biochemical, and family studies for investigation of patients who have partially deleted chromosomes provides a potential opportunity to learn what genes were present on the fragment deleted from the chromosome. In addition, the genes on its remaining homologue can be studied in their hemizygous state. The ring chromosome, an example of a partially deleted chromosome by the currently accepted mechanism for ring formation, has lost chromatin from the distal portion of both its long and short arms (McClintock, 1932).

Of the cases shown to have ring $\mathrm{D}$ chromosomes (Wang et al, 1962; Bain and Gauld, 1963; Turner, 1963; Adams, 1965; Reisman, Darnell, and Murphy, 1965; Bloom, Gerald, and Reisman, 1967; Gerald et al, 1967; Sparkes, Carrel, and Wright, 1967; Teplitz et al, 1967; Lejeune et al, 1968; Masterson et al, 1968; Allderdice et al, 1969), two cases appeared to be hemizygous for the structural gene for the alpha chain of haptoglobin (Bloom et al, 1967; Gerald et al, 1967). One locus was presumed lost during ring formation. In contrast to these observations, we now report a patient who had a ring chromosome No. 13 in 3 tissues studied, but who showed no evidence of loss of a haptoglobin-gene locus.

\footnotetext{
Received 6 July 1970.

* A part of this study was presented to the annual meeting of the Southern Society for Pediatric Research, Charlottesville, Virginia in November 1967 and was reported in abstract form in (Hollowell et al, 1967). The study was supported in part by PHS grant HD-01429 and HD-00353, HD-02724, HE-04706, GRS grant FR5365 and National Foundation CRCS no. 55.

† Present address: University of Kansas Medical Center; 39th Street at Rainbow Boulevard; Kansas City, Kansas 66103, USA.

¥ Present address: Oak Ridge Associated Universities; Oak Ridge Institute of Nuclear Studies; Oak Ridge, Tennessee 37830, USA.

** Present address: University of Florida School of Medicine, Gainesville, Florida 32601, USA.
}

\section{Case Report}

This Caucasian female was born 7 August 1964 at 38 weeks gestation, weighing $2300 \mathrm{~g}$. There were no illnesses, drugs, or $x$-rays during gestation. During the first few months of life, she had cyanosis, clubbing of the nails, and suspected tetralogy of Fallot. A left cavernous haemangioma, present at birth, grew slowly until 3 months of age when it suddenly enlarged. At that time she had thrombocytopenia, presumably due to platelet trapping by the haemangioma. She received a course of $x$-ray therapy to the haemangioma which regressed promptly. Her development was delayed.

This was the only child of a mother aged 19 and a father aged 21 at the child's birth. They have since been divorced. There was no infertility, miscarriage, or other significant family history.

Physical examination at 3 years showed a small, retarded girl with microcephaly, epicanthal folds, almondshaped eyes, large, structurally normal ears, prominent nasal bridge, cyanosis, and clubbing of the fingers and toes. The nipples were hypoplastic (Fig. 1). The height $(87 \mathrm{~cm})$, weight $(1050 \mathrm{~g})$ were less than a third centile. The head circumference $(42.5 \mathrm{~cm})$ was proportionately much smaller than body length. Facial asymmetry and hypoplasia of the left maxillary alveolar ridge were attributed to $x$-ray therapy, although facial asymmetry has been described in the $\mathrm{Dq}$ - syndrome (Allerdice et al, 1969). Findings at cardiac catheterization were consistent with tetralogy of Fallot. There was no craniostenosis. $X$-rays of bones were normal. Dermatoglyphic studies revealed a total ridge count of 76 , atd angle of $51^{\circ}$ on both hands, and slight ulnar displacement of the axial triradius.

Cytogenetic Studies (Table I). Chromosome analysis on peripheral blood by a modified method of Moorhead et al (1960) showed 46 chromosomes, only $5 \mathrm{D}$ chromosomes, and a ring chromosome in each of the 73 cells studied. The ring was thought to represent the missing D chromosome. There were three cells with 45 chromosomes showing random loss of chromosomes. The ring was quite variable in configuration and size 

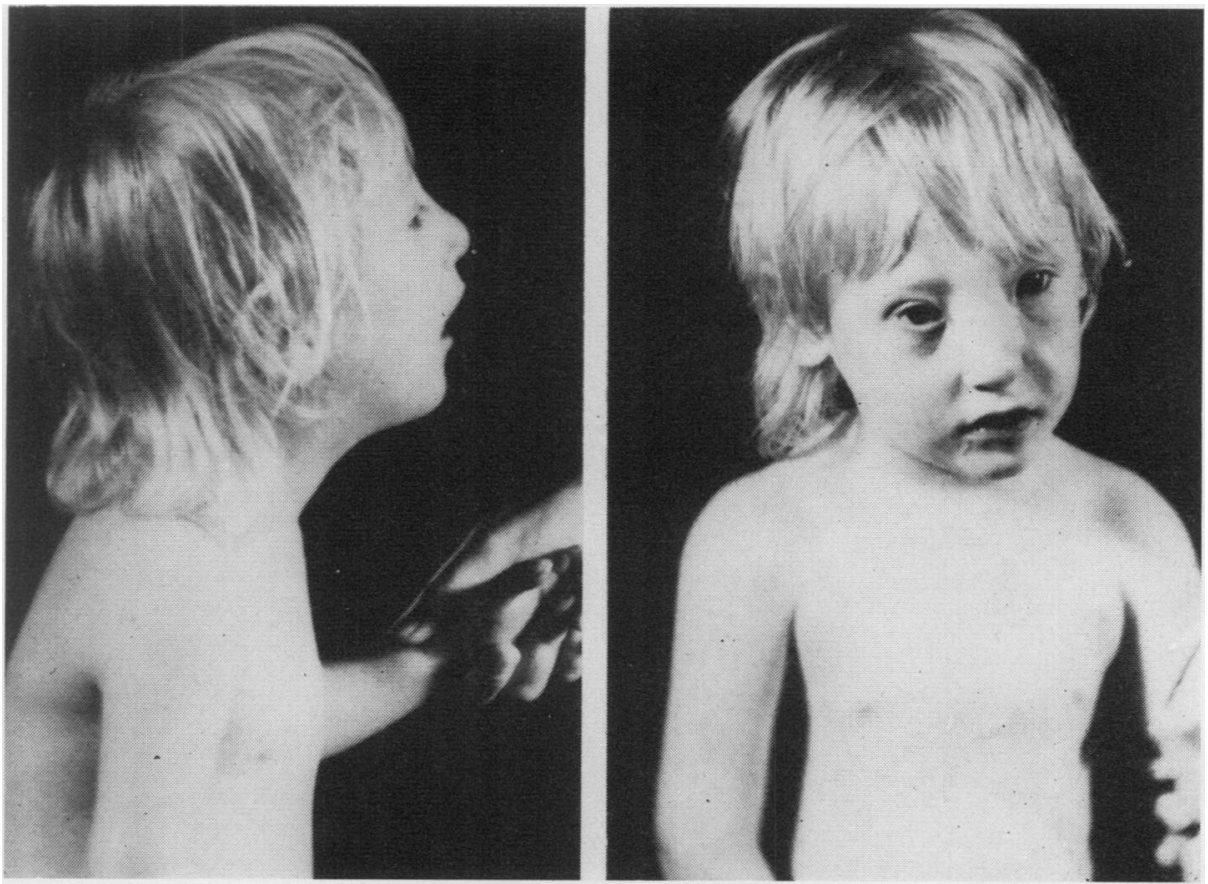

Fig. 1. Patient, at 3 years of age, showing unusual facies, almond-shaped eyes, epicanthal folds, and prominent nose. The ears were large, but structurally normal. The digits were clubbed.

from cell to cell (Fig. 2). Autoradiography was done at the end of 72 hours' incubation using $0.06 \mu \mathrm{C} / \mathrm{ml}^{3} \mathrm{H}$ thymidine during the last 6 hours of incubation and colchicine for the last 3 hours (Schmid, 1963). Slides were coated with liquid photographic emulsion (Kodak NTB-3) and exposed for 6 days. Cells in which the D chromosomes were differentially labelled and suitable for analysis were photographed. After degraining the emulsion, the cells were re-photographed for comparison with the autoradiographs.

A discernible labelling pattern was found in 36 cells which were technically satisfactory for study. Chromosome No. 13, by convention, is the late-replicating, large acrocentric chromosome in which the late-replication occurs distally in the long arms (German, 1964; Yunis, Hook, and Mayer, 1964). In our patient one such late-labelling $\mathrm{D}$ chromosome was found in 35 cells; whereas, there were two earlier-replicating D chromo-

\section{TABLE I}

\begin{tabular}{l|c|c|c|c|c|c}
\hline & $\begin{array}{c}\text { Peripheral } \\
\text { Blood }\end{array}$ & $\begin{array}{c}\text { Skin } \\
\text { Culture }\end{array}$ & \multicolumn{2}{|c}{$\begin{array}{c}\text { Bone } \\
\text { Marrow }\end{array}$} \\
\cline { 2 - 6 } Chromosomes per cell & $<46$ & 46 & $<46$ & 46 & $<46$ & 46 \\
\hline $\begin{array}{c}\text { Cells counted } \\
\text { Cells with 6 normal D chro- } \\
\text { mosomes }\end{array}$ & 3 & 73 & 20 & 23 & 4 & 23 \\
$\begin{array}{c}\text { Cells with recognizable or } \\
\text { probable ring }\end{array}$ & 0 & 0 & 0 & 0 & 0 & 0 \\
\hline
\end{tabular}

somes (No. 15) and two D chromosomes with heavy labelling in the region of the centromeres and light labelling over the long arms (No. 14). A labelling pattern different from this was found in one cell. In addition, the ring labelled to nearly the same extent as the normal No. 13 (Fig. 2). We interpret these findings to indicate that chromosome No. 13 was present as a ring chromosome. The mother's chromosomes were found to be normal in 25 cells studied. The father was unavailable for study.

Cells cultured from a skin biopsy were harvested on the second sub-culture and the chromosomes studied. There were 46 chromosomes in 23 cells of which 14 had $5 \mathrm{D}$ chromosomes and a recognizable ring and 9 had $5 \mathrm{D}$ chromosomes but the ring was not clearly identified. Twenty cells had 45 chromosomes; the ring was present in 6 , absent in 12, and not clear in 2 of these cells. In no cell were more than 5 normal $D$ chromosomes found. There were no consistent abnormalities seen other than the ring chromosome. No cells were found to contain a normal complement of 46 chromosomes. Cells from bone marrow were studied after 48 hours' incubation. There were 23 cells which contained 46 chromosomes (5 D's and a recognizable or probable ring). Other cells had the loss of various chromosomes, but a ring was found in each of the 27 cells studied. In no cell were more than 5 normal D chromosomes found.

Haptoglobin Studies. Plasma haptoglobin types were determined using vertical starch gel electrophoresis 


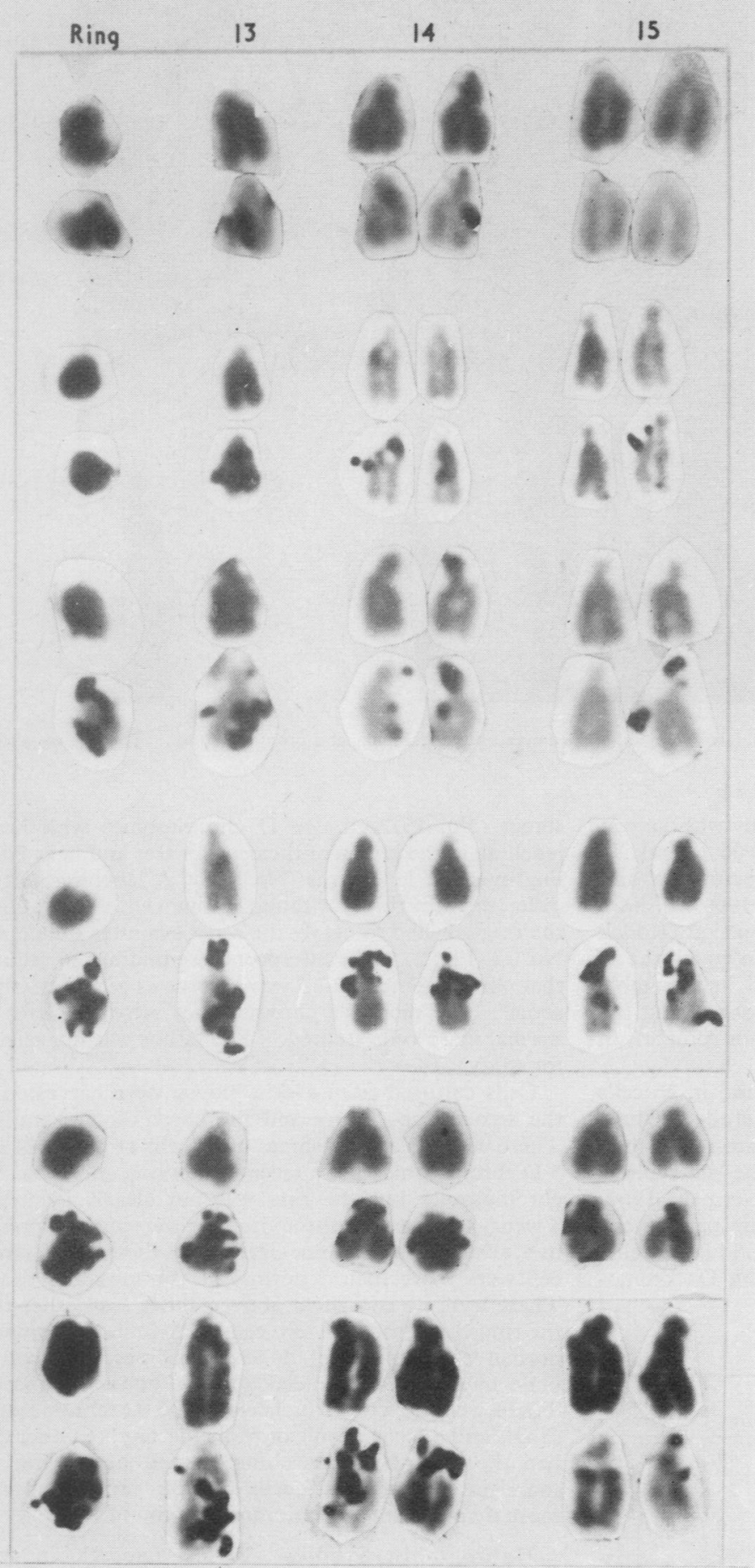

FIG. 2. Chromosomal autoradiography and variation in ring chromosome. As indicated by autoradiography, one No. $\omega$ 13 chromosome was missing and was thought to be present as the ring chromosome. The ring was quite variable in appearance from cell to cell.

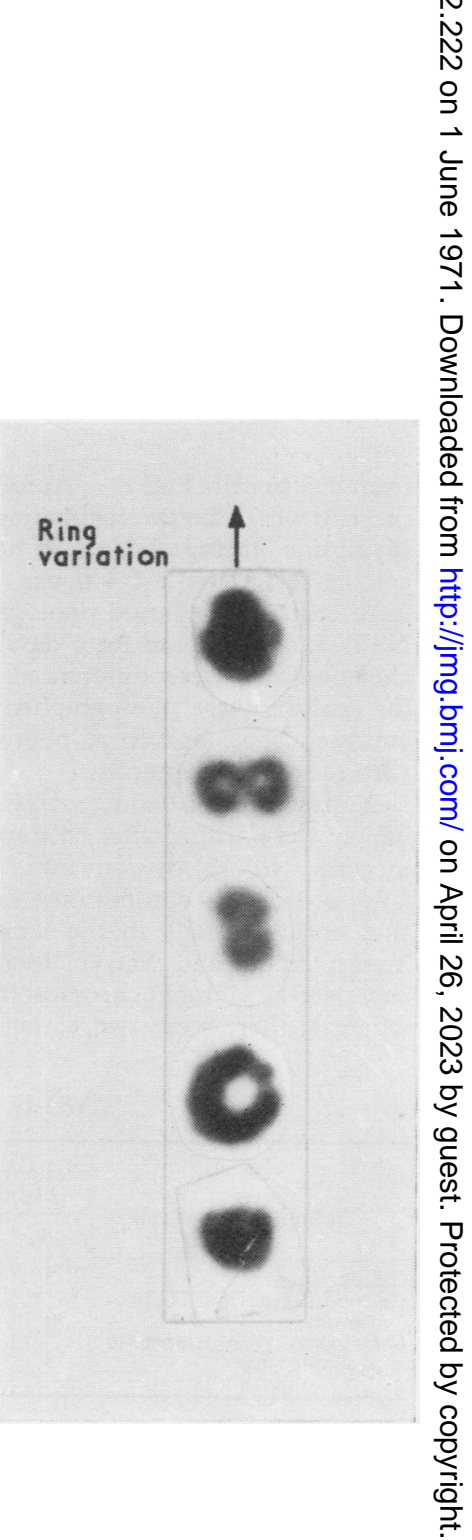


for separation of haemoglobin-haptoglobin complexes (Smithies, 1955). After an overnight run, benzidene staining of the gels identified the haptoglobin complexes.

In this patient, a pattern was found that was identical to the usual pattern of heterozygous haptoglobin 2-1, demonstrating the presence of 2 separate haptoglobin gene loci. The mother's haptoglobin was homozygous 2-2. Studies of additional plasma samples from the patient and her mother confirmed these findings. There were no inconsistencies in other blood groups studied (Table II).

\section{Discussion}

Gerald and his coworkers reported ring chromosome No. 13 in two patients who apparently failed to inherit a haptoglobin gene from a parent. The anomalous inheritance of haptoglobin was explained by the deletion of the gene locus during ring formation. Inheritance of a variant inert gene offered another explanation which could not be excluded in their first patient (Gerald et al, 1967). The second patient inherited a variant weak haptoglobin gene from the father, but was ahaptoglobinaemic suggesting deletion of the maternal gene (Bloom et al, 1967).

TABLE II

There were negative results for antigens $\mathrm{Vw}, \mathrm{M}^{\mathrm{g}}$, and $\mathrm{Wr}^{\mathrm{a}}$.

\begin{tabular}{|c|c|c|}
\hline & \multicolumn{2}{|c|}{ Name } \\
\hline & Mother of proposita & Proposita \\
\hline $\begin{array}{l}A_{1} \\
H \\
A \\
B\end{array}$ & $\begin{array}{l}0 \\
+ \\
0 \\
0\end{array}$ & $\begin{array}{l}0 \\
+ \\
+ \\
0\end{array}$ \\
\hline $\begin{array}{l}\text { Rhesus: } \\
1 \mathrm{D} \\
2 \mathrm{C} \\
3 \mathrm{E} \\
4 \mathrm{c} \\
5 \mathrm{e} \\
6 \mathrm{f} \\
8 \mathrm{C} w\end{array}$ & $\begin{array}{l}+ \\
+ \\
0 \\
+ \\
+ \\
0\end{array}$ & $\begin{array}{l}+ \\
0 \\
0 \\
+ \\
+ \\
0\end{array}$ \\
\hline$P_{1}$ & + & + \\
\hline $\begin{array}{l}\mathrm{K}: \\
1 \mathrm{~K} \\
3 \mathrm{~K} \mathrm{p}^{\mathrm{a}} \\
4 \mathrm{~K} \mathrm{p}^{\mathrm{b}}\end{array}$ & $\begin{array}{l}0 \\
0 \\
+\end{array}$ & $\begin{array}{l}0 \\
0 \\
+\end{array}$ \\
\hline $\begin{array}{l}\mathrm{Le}^{\mathrm{a}} \\
\mathrm{Le}^{\mathrm{b}}\end{array}$ & $\begin{array}{l}0 \\
+\end{array}$ & $\begin{array}{l}0 \\
+\end{array}$ \\
\hline $\begin{array}{l}M \\
\text { N } \\
S \\
s\end{array}$ & $\begin{array}{l}+ \\
0 \\
+ \\
+\end{array}$ & $\begin{array}{l}+ \\
0 \\
+ \\
0\end{array}$ \\
\hline $\begin{array}{l}\mathrm{L} \mathrm{u}^{\mathrm{a}} \\
\mathrm{Lu}^{\mathrm{b}}\end{array}$ & $\begin{array}{l}0 \\
+\end{array}$ & 0 \\
\hline$F y^{a}$ & + & + \\
\hline $\mathrm{Jk}^{\mathrm{a}}$ & + & + \\
\hline $\mathrm{Hp}$ & $2-2$ & $2-1$ \\
\hline $\operatorname{Tf}$ & C & $\mathrm{C}$ \\
\hline
\end{tabular}

7-J.M.G.
Our patient with terminal deletions of portions of chromosome No. 13 had a heterozygous haptoglobin type, thus evidence for the presence of both haptoglobin loci. These findings do not support the loss of gene locus hypothesis proposed by Gerald. Chromosomal mosaicism was considered to explain the haptoglobin heterozygosity, but finding no normal cells in the 3 tissues studied made this possibility less likely. Because of the wide distribution of the single chromosome abnormality, the absence of normal cells and the lack of other chromosome aberrations, it is unlikely that the $x$-ray given to the patient at 3 months of age was responsible for the formation of the ring.

Haptoglobin heterozygosity was reported in a patient with ring chromosome No. 14 by Sparkes et al (1967) and by Coffin and Wilson (1970) in a patient with ring 13 chromosome. A fragment was present in some of the cells of the latter. Bias and Migeon (1967) reported a family in which four members had a telocentric chromosome No. 13 and a heterozygous haptoglobin type indicating that the haptoglobin genes were not located on the short arms of that chromosome.

Additional supportive evidence for the deletion hypothesis has not been forthcoming. Cook et al (1969) described a family in which both mother and child had probable deletion of the long arm of chromosome No. 13. They showed anomalous segregation of haptoglobin types, but similar anomalous segregation was discovered in individuals with normal karyotypes in another branch of that family leading them to explain their findings on the basis of a 'silent' haptoglobin allele segregating in the family rather than chromosome deletion. They were not compelled to accept the assignment of the $\alpha$-chain haptoglobin locus to chromosome 13 on the basis of available evidence.

It is possible to reconcile the haptoglobin heterozygosity in our patient with $46, \mathrm{XX}, 13 \mathrm{r}$ in the light of findings which place the haptoglobin loci on chromosome No. 13 by assuming less genetic material to be lost in the formation of the ring chromosome in our patient than in patients studied previously. In view of the recent linkage data of Robson et al (1969), a more likely possibility at present may be that the haptoglobin locus is not located on chromosome No. 13 at all. From a large pedigree they found that the $\mathrm{Hp}-1$ allele segregated in coupling with a translocation between chromosome No. 2 and chromosome No. 16. Their findings were supported by data from other families with marker 16 chromosomes and offer strong evidence that the locus is on chromosome 16. 


\section{Summary}

A patient with tetralogy of Fallot, unusual facies, mental retardation, and microcephaly is described. The patient has a ring chromosome 13 in three cell lines and heterozygosity of haptoglobin genotype. The findings in the present case do not support the hypothesis from chromosome deletion mapping that the haptoglobin locus is on chromosome No. 13. The possibility should be considered that the haptoglobin gene is located on a different chromosome probably No. 16 in view of recent linkage data.

The authors are grateful for the technical assistance of Sylvia Littlejohn and Mary Beth Orosz. We thank Mrs Lillie Bruce and Jan Getz for help in preparing the manuscript.

\section{REFERENCES}

Adams, M. S. (1965). Palm-prints and a ring-D chromosome. Lancet, 2, 494-495.

Allderdice, P. W., Davis, J. G., Miller, O. J., Klinger, H. P., Warburton, D., Miller, D. A., Allen, F. H., Jr., Abrams, C. A. L., and McGilvray, E. (1969). The 13q-Deletion Syndrome. American Fournal of Human Genetics, 21, 499-512.

Bain, A. D. and Gauld, I. K. (1963). Multiple congenital abnormalities associated with ring chromosome. Lancet, 2, 304-305.

Bias, W. B. and Migeon, B. R. (1967). Haptoglobin: a locus on the D1 chromosome? American fournal of Human Genetics, 19, 393398.

Bloom, G. E., Gerald, P. S., and Reisman, L. E. (1967). Ring D Chromosome-A second case associated with anomalous haptoglobin inheritance. Science, 156, 1746-1748.

Coffin, G. S. and Wilson, M. G. (1970). Ring Chromosome D (13). American fournal of Diseases of Children, 119, 370-373.

Cook, P. J. L., Gray, J. E., Brack, R. A., Robson, E. B., and Howlett, R. M. (1969). Data on haptoglobin and the D group chromosomes. Annals of Human Genetics, 33, 125-138.
Gerald, P. S., Warner, S., Singer, J. D., Corcoran, P. A., and Umansky, I. (1967). A ring D chromosome and anomalous inheritance of haptoglobin type. Fournal of Pediatrics, 70, 172-179.

German, J. (1964). The pattern of DNA synthesis in the chromosomes of human blood cells. Fournal of Cell Biology, 20, 37-55.

Hollowell, J. G., Littlefield, L. G., and Bloom, G. E. (1967). Ring D chromosome with anomalous haptoglobin inheritance. (Abstr.) Southern Medical fournal, 60, 1355.

Lejeune, J., LaFourcade, J., Berger, R., Cruveiller, J., Rethoré, M.O., Dutrillaux, B., Abonyi, D., and Jérôme, H. (1968). Le Phénotype (Dr). Étude de trois cas de chromosomes D en anneau. Annales de Génétique, 11, 79-87.

McClintock, B. (1932). A correlation of ring-shaped chromosomes with variegation in Zea Mays. Proceedings of the National Academy of Sciences of the United States of America, 18, 677-681.

Masterson, J. G., Cahalane, S. F., Law, E. M., Kavanagh, T. M., and Rashad, M. N. (1968). A malformation syndrome with ring D chromosome. Fournal of the Irish Medical Association, 61, 398-399.

Moorhead, P. S., Nowell, P. C., Mellman, W. J., Battips, D. M., and Hungerford, D. A. (1960). Chromosome preparations of leukocytes cultured from human peripheral blood. Experimental Cell Research, 20, 613-616.

Reisman, L. E., Darnell, A., and Murphy, J. W. (1965). Abnormalities with ring chromosome. Lancet, 2, 445.

Robson, E. B., Polani, P. E., Dart, S. J., Jacobs, P. A., and Renwick, J. H. (1969). Probable assignment of the alpha locus of haptoglobin to chromosome 16 in man. Nature, 223, 1163-1165.

Schmid, W. (1963). DNA replication patterns of human chromosomes. Cytogenetics, 2, 175-193.

Smithies, O. (1955). Zone electrophoresis in starch gels: group variations in serum proteins of normal human adults. Biochemical fournal, 61, 629-641.

Sparkes, R. S., Carrel, R. E., and Wright, S. W. (1967). Absent thumbs with a ring $\mathrm{D}_{2}$ chromosome: a new deletion syndrome. American fournal of Human Genetics, 19, 644-659.

Teplitz, R. L., Miller, D., Hansson, K. M., and Rundall, T. S. (1967). A human ring D chromosome associated with multiple congenital abnormalities. Fournal of Pediatrics, 70, 936-941.

Turner, B. (1963). Cytogenetic studies in mental retardation. Proceedings of the Australian Association of Neurologists, 1, 41-42.

Wang, H. C., Melnyk, J., McDonald, L. T., Uchida, I. A., Carr, D. H., and Goldberg, B. (1962). Ring chromosomes in human beings. Nature, 195, 733-734.

Yunis, J. J., Hook, E. B., and Mayer, M. (1964). Deoxyribonucleic-acid replication pattern of trisomy $\mathrm{D}_{1}$. Lancet, $2,935-$ 937. 